\title{
Influence of the Culture Medium on the Production of Iturin A by Bacillus subtilis
}

\author{
By FRANÇOISE BESSON, * CATHERINE CHEVANET AND \\ GEORGES MICHEL \\ Laboratoire de Biochimie Microbienne, Université Claude Bernard, Lyon I, \\ 34 Boulevard du 11 Novembre 1918, 69622 Villeurbanne Cedex, France
}

(Received 17 April 1986; revised 19 June 1986)

The production of iturin A by Bacillus subtilis was studied with respect to the composition of the culture medium. Increasing phosphate concentrations did not modify the antibiotic yield. Fructose, sucrose and mannitol were better carbon sources than glucose for antibiotic production. The nature of the nitrogen source was an important factor in the production of antibiotic. Among the amino acids which are components of iturin A, L-asparagine was the best substrate for the biosynthesis of iturin A; L-glutamine and L-serine were rather poor substrates while L-proline and D-tyrosine gave no antibiotic. Ammonium salts permitted good synthesis of antibiotic but the addition of calcium ions to the culture medium inhibited the excretion of antibiotic from the cells.

\section{INTRODUCTION}

Iturin $\mathrm{A}$ is an antifungal antibiotic produced by several strains of Bacillis subtilis (Besson et al., 1976). Its chemical structure (Fig. 1) has been determined (Peypoux et al., 1978): it is a cyclolipopeptide containing two residues of $D$-asparagine, one residue each of $L$-asparagine, $L$ glutamine, L-proline, $\mathrm{L}$-serine and $\mathrm{D}$-tyrosine and one residue of a liposoluble $\beta$-amino acid with an $n-\mathrm{C}_{14}$, iso- $\mathrm{C}_{15}$, anteiso- $\mathrm{C}_{15}$, iso- $\mathrm{C}_{16}$ or $n-\mathrm{C}_{16}$ chain (Isogai et al., 1982).

It is well known that the production of most antibiotics is dependent on the composition of the culture medium in which the producer micro-organism is grown. Carbon and nitrogen catabolite regulation, phosphate regulation and induction appear to be general regulatory mechanisms that control the onset of antibiotic synthesis (Martin \& Demain, 1980). The regulatory effects of amino acids on peptide antibiotic synthesis have been reported for colistin (Ito et al., 1969), actinomycin (Katz, 1960; Katz et al., 1961), tyrocidin (Mach \& Tatum, 1964), gramicidin (Matteo et al., 1975; Vandamme \& Demain, 1976), echinomycin (Formica \& Waring, 1983), bacitracin (Haavik, 1979, 1981) and antibiotic K-582 (Ito-Kawaga et al., 1983).

Iturin A has been isolated from a complex medium (Besson et al., 1976). In order to compare the factors which might affect the production of iturin $\mathbf{A}$, we screened a number of carbon and nitrogen sources.

\section{METHODS}

Culture conditions. A strain of B. subtilis producing iturin was kindly supplied by Dr L. Delcambe, CNPEM, Liège, Belgium. It was grown at $35^{\circ} \mathrm{C}$ for $50 \mathrm{~h}$ on a basal medium containing $\left(\mathrm{g} \mathrm{l}^{-1}\right)$ : glucose, $10 ; \mathrm{KH}_{2} \mathrm{PO}_{4}, 1$; $\mathrm{MgSO}_{4} .7 \mathrm{H}_{2} \mathrm{O}, 0 \cdot 5 ; \mathrm{KCl}, 1 ; \mathrm{Fe}_{2}\left(\mathrm{SO}_{4}\right)_{3} .6 \mathrm{H}_{2} \mathrm{O}, 5 \times 10^{-3} ; \mathrm{CuSO}_{4} .5 \mathrm{H}_{2} \mathrm{O}, 0 \cdot 16 \times 10^{-3}$ and glutamic acid, $5(34 \mathrm{mM})$. In some experiments, glucose was replaced by other carbon sources at the same concentration $\left(10 \mathrm{~g} \mathrm{l}^{-1}\right)$, and glutamic acid by other nitrogen sources at the same molarity ( $34 \mathrm{~mm}$ ). In other experiments, the phosphate concentration was increased from $0 \cdot 1$ to $100 \mathrm{~mm}$. The $\mathrm{pH}$ of the media was adjusted to $7 \cdot 7$ before autoclaving. Growth was estimated as $\mathrm{OD}_{600}\left(10^{5}\right.$ cells $\mathrm{ml}^{-1}$ corresponds to an optical density of about 1$)$.

Quantitative determination of iturin. Crude preparations of antibiotic were obtained by acidification of culture medium, and the presence of iturin was detected by the characterization of $\beta$-amino acids after total hydrolysis with $6 \mathrm{M}-\mathrm{HCl}$ at $150^{\circ} \mathrm{C}$ for $8 \mathrm{~h}$ as described previously (Besson et al., 1976). For quantitative analysis, samples of the chloroformic extract (corresponding to $100 \mathrm{nmol}$ of $\beta$-amino acids) were dinitrophenylated with 1 -fluoro-2,4- 


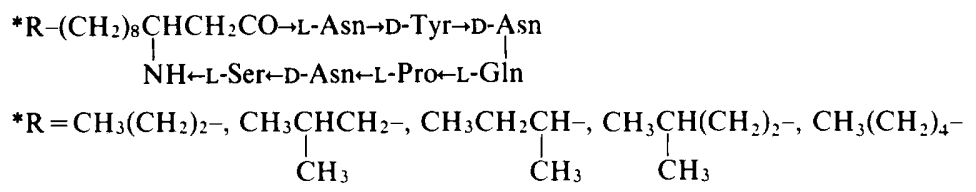

Fig. 1. Structure of iturin A.

dinitro $\left[{ }^{1+} \mathrm{C}\right]$ benzene, specific activity $7.4 \mathrm{MBq} \mathrm{mmol}^{-1}$ (Amersham) (Chevanet et al., 1986); the dinitrophenyl $\beta$ amino acids were purified by chromatography on silica gel 60 (Merck) in chloroform/methanol/acetic acid $(95: 5: 1$, by vol.) and their radioactivities were measured in a liquid scintillation spectrometer (Packard Tricarb 2001) with Ready Solv EP scintillation fluid (Beckman). Standards of radioactive dinitrophenyl $\beta$-amino acids were obtained by dinitrophenylation of $25-200 \mathrm{nmol}$ of pure $\beta$-amino acids.

Determination of antibiotic activity by bioautography. Antibiotic activity was located on thin-layer chromatograms by the detection of antifungal activity on Sabouraud agar cultures of Saccharomyces cerevisiae (Besson et al., 1978).

\section{RESULTS}

Growth and iturin production. Fig. 2 shows the course of iturin production by $B$. subtilis grown in basal medium, growth and the changes in $\mathrm{pH}$ and glucose concentration of the culture medium. During the first $15 \mathrm{~h}$ of cultivation, growth was exponential. Iturin production began at the end of the exponential phase, when the glucose was almost exhausted, and increased markedly until $45 \mathrm{~h}$. The relation between growth and iturin production showed a typical trophophase-idiophase pattern. The variations of $\mathrm{pH}$ were slight, between 5.6 and 6.8.

Effect of phosphate on iturin production. Increasing phosphate concentrations in the basal medium increased both growth and antibiotic production but did not modify the relative antibiotic yield (Table 1). The effect of increased buffer strength on iturin production was also studied by adding $50 \mathrm{~mm}$-HEPES to 0.1 and $1 \mathrm{~mm}$-phosphate media; the $\mathrm{pH}$ was maintained at 7.5 and no variation in the antibiotic production was observed.

Effect of carbon sources on iturin production. Glucose in the basal medium was replaced by the same concentration $\left(10 \mathrm{~g} \mathrm{l}^{-1}\right)$ of fructose, sucrose, glycerol, mannitol, citric acid or lactic acid (Table 2). Fructose, sucrose and mannitol were better substrates than glucose for antibiotic synthesis. With glycerol, the growth was good but the yield of antibiotic was lowered; citric acid and lactic acid were poor substrates for growth, although citric acid gave a normal yield of antibiotic.

Effect of amino acids on iturin production. The abilities of several amino acids, as sole nitrogen sources, to support growth of the organism and the production of antibiotic were tested (Table 3). All the amino acids which are components of iturin A or which could be precursors of iturin A gave normal growth except tyrosine. L-Glutamic acid, L-glutamine, D- and L-aspartic acid, Lasparagine and L-serine supported antibiotic production whereas L-proline did not. The highest yields were obtained with L-glutamic acid, L- and D-aspartic acid and L-asparagine. Replacement of L-asparagine by $\mathrm{D}$-asparagine decreased iturin production.

Some structural analogues of the peptide precursors were also tested. Among them, only DLthreonine supported antibiotic production, but at a low level.

Another antibiotic related to iturin, bacillomycin F, isolated from another $B$. subtilis strain (Mhammedi et al., 1982) contains a threonyl residue instead of the seryl residue in iturin A (Peypoux et al., 1985). Thus, the precise nature of the antibiotic produced in the presence of threonine was determined. Crude antibiotic preparation obtained with addition of threonine in the culture medium was purified by chromatography on silicic acid columns as described previously (Peypoux et al., 1973). The fractions were examined by thin-layer chromatography on silica gel 60 with the solvent chloroform/methanol/water $(65: 25: 4$, by vol.), detected by Pauly reagent (Jutisz, 1960) or by their antifungal activities on Saccharomyces cerevisiae. Bioautograms and Pauly reactions revealed the presence of iturin A only; no bacillomycin F was detected.

The effects of DL-alanine, DL-leucine, DL-isoleucine and DL-valine were also studied. DLLeucine and DL-valine did not support antibiotic synthesis; with DL-isoleucine, antibiotic was 

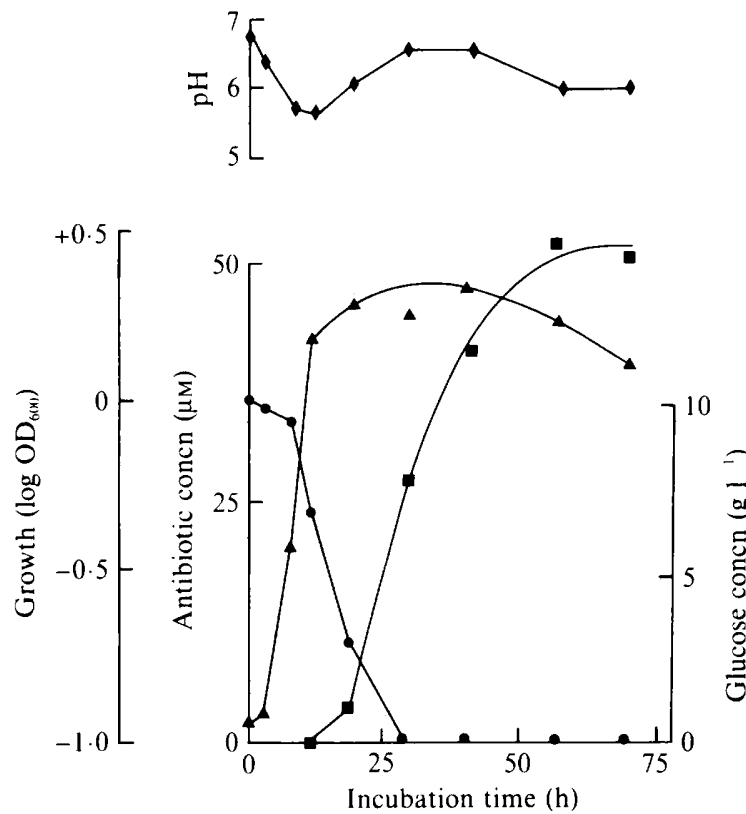

Fig. 2. Iturin A production in the basal medium. Antibiotic concentration ( $\square$ ) was determined in relation to growth $(\mathbf{\Lambda})$, and the $\mathrm{pH}(\bullet)$ and glucose concentration $(\boldsymbol{O})$ of the culture medium. The data points are means of three assays.

Table 1. Effect of phosphate on iturin production after $50 \mathrm{~h}$ growth

$\begin{array}{ccccc}\begin{array}{c}\text { Phosphate } \\ \text { concn } \\ (\mathrm{mM})\end{array} & \begin{array}{c}\text { Growth* } \\ \left(\mathrm{OD}_{600}\right)\end{array} & \mathrm{pH}^{*} & \begin{array}{c}\text { Antibiotic } \\ \text { in medium* } \\ (\mu \mathrm{M})\end{array} & \begin{array}{c}\text { Antibiotic yield } \\ (\mu \mathrm{mol} \text { per } \\ \left.\mathrm{OD}_{600} \text { unit }\right)\end{array} \\ 0 \cdot 1 & 3 \cdot 3 \pm 0 \cdot 1 & 8 \cdot 7 \pm 0 \cdot 1 & 37 \pm 1 & 12 \\ 1 & 3 \cdot 2 \pm 0 \cdot 1 & 8 \cdot 5 \pm 0 \cdot 1 & 41 \pm 3 & 13 \\ 10 & 4 \cdot 6 \pm 0 \cdot 4 & 6 \cdot 2 \pm 0 \cdot 3 & 59 \pm 1 & 13 \\ 100 & 5 \cdot 1 \pm 0 \cdot 1 & 6 \cdot 5 \pm 0 \cdot 1 & 68 \pm 1 & 13 \\ \end{array}$

Table 2. Effect of different carbon sources on iturin production after $50 \mathrm{~h}$ growth

\begin{tabular}{|c|c|c|c|}
\hline Carbon sources & $\begin{array}{l}\text { Growth* } \\
\left(\mathrm{OD}_{600}\right)\end{array}$ & $\begin{array}{l}\text { Antibiotic* } \\
\text { in medium } \\
(\mu \mathrm{M})\end{array}$ & $\begin{array}{l}\text { Antibiotic yield } \\
(\mu \text { mol per } \\
\left.\text { OD }_{600} \text { unit }\right)\end{array}$ \\
\hline ic acid alone $\dagger$ & $2 \cdot 4 \pm 0 \cdot 1$ & $4 \pm 1$ & 2 \\
\hline ic acid + glucose + & $4.4 \pm 0 \cdot 1$ & $53 \pm 2$ & 12 \\
\hline+ fructose & $5.0 \pm 0.2$ & $116 \pm 3$ & 23 \\
\hline+ sucrose & $5.6 \pm 0.1$ & $118 \pm 6$ & 21 \\
\hline + glycerol & $6.0 \pm 0.2$ & $50 \pm 7$ & 8 \\
\hline + mannitol & $4.6 \pm 0.5$ & $149 \pm 9$ & 32 \\
\hline+ citric acid & $1.5 \pm 0.1$ & $20 \pm 5$ & 13 \\
\hline+ lactic acid & $2.4 \pm 0.3$ & $8 \pm 1$ & 3 \\
\hline
\end{tabular}

* The values are the mean of at least two assays, \pm the range of results.

$\dagger B$. subtilis was grown for $5 \mathrm{~d}$ (instead of $50 \mathrm{~h}$ ) in this medium.

$\ddagger$ This medium is the basal medium. 
F. BESSON, C. CHEVANET AND G. MICHEL

Table 3. Effect of amino acids on iturin production after $50 \mathrm{~h}$ growth

\begin{tabular}{|c|c|c|c|}
\hline $\begin{array}{l}\text { Amino acid* } \\
(34 \mathrm{mM})\end{array}$ & $\begin{array}{l}\text { Growth† } \\
\left(\mathrm{OD}_{600}\right)\end{array}$ & $\begin{array}{l}\text { Antibiotic } † \\
\text { in medium } \\
(\mu \mathrm{M})\end{array}$ & $\begin{array}{c}\text { Antibiotic yield } \\
\text { ( } \mu \text { mol per } \\
\left.\text { OD }_{600} \text { unit }\right)\end{array}$ \\
\hline $\begin{array}{l}\text { L-Glutamine } \\
\text { L-Glutamic acid } \ddagger\end{array}$ & $\begin{array}{l}4.4 \pm 0.2 \\
4.4 \pm 0.1\end{array}$ & $\begin{array}{l}12 \pm 2 \\
53 \pm 2\end{array}$ & 12 \\
\hline $\begin{array}{l}\text { D-Asparagine } \\
\text { L-Asparagine } \\
\text { D-Aspartic acid } \\
\text { L-Aspartic acid }\end{array}$ & $\begin{array}{l}4 \cdot 8 \pm 0.3 \\
4 \cdot 6 \pm 0.2 \\
3 \cdot 8 \pm 0.3 \\
2 \cdot 1 \pm 0.1\end{array}$ & $\begin{array}{l}13 \pm 1 \\
65 \pm 4 \\
40 \pm 2 \\
23 \pm 1\end{array}$ & $\begin{array}{r}3 \\
14 \\
11 \\
11\end{array}$ \\
\hline $\begin{array}{l}\text { L-Serine } \\
\text { DL-Threonine } \\
\text { DL-Homoserine }\end{array}$ & $\begin{array}{l}3.8 \pm 0.3 \\
2.7 \pm 0.4 \\
4.4 \pm 0.1\end{array}$ & $\begin{array}{c}16 \pm 2 \\
7 \pm 1 \\
0\end{array}$ & $\begin{array}{c}4 \\
2 \\
-\end{array}$ \\
\hline $\begin{array}{l}\text { D-Tyrosine } \\
\text { L-Tyrosine } \\
\text { DL-Phenylalanine }\end{array}$ & $\begin{array}{c}0 \\
0 \\
2 \cdot 0 \pm 0 \cdot 1\end{array}$ & $\begin{array}{l}- \\
- \\
0\end{array}$ & $\begin{array}{l}- \\
- \\
-\end{array}$ \\
\hline L-Proline & $10.0 \pm 0.4$ & 0 & - \\
\hline $\begin{array}{l}\text { DL-Alanine } \\
\text { DL-Isoleucine } \\
\text { DL-Leucine } \\
\text { DL-Valine }\end{array}$ & $\begin{array}{l}5.2 \pm 0.2 \\
1.8 \pm 0.1 \\
1.8 \pm 0.3 \\
1.4 \pm 0.1\end{array}$ & $\begin{array}{c}30 \pm 3 \\
2 \pm 1 \\
0 \\
0\end{array}$ & $\begin{array}{c}6 \\
1 \\
- \\
-\end{array}$ \\
\hline
\end{tabular}

Table 4. Effect of ammonium ions on iturin production after $50 \mathrm{~h}$ growth

\begin{tabular}{|c|c|c|c|c|c|c|}
\hline \multirow{2}{*}{$\begin{array}{c}\text { Nitrogen source } \\
(34 \mathrm{mM})\end{array}$} & \multirow{2}{*}{$\begin{array}{l}\text { Growth* } \\
\left(\mathrm{OD}_{600}\right)\end{array}$} & \multirow[b]{2}{*}{$\mathrm{pH}^{*}$} & \multicolumn{2}{|c|}{ Antibiotic* } & \multicolumn{2}{|c|}{$\begin{array}{l}\beta \text {-Amino acids } \\
\text { in cells* }\end{array}$} \\
\hline & & & In medium & In cells & Free & After hydrolysis \\
\hline L-Glutamic acid $\dagger$ & $4 \cdot 4 \pm 0 \cdot 2$ & $7 \cdot 0 \pm 0 \cdot 1$ & $53 \pm 2$ & 0 & 0 & 0 \\
\hline $\mathrm{NH}_{4} \mathrm{Cl}$ & $3 \cdot 2 \pm 0 \cdot 1$ & $4 \cdot 2 \pm 0 \cdot 1$ & $\overline{0}$ & 0 & 0 & 0 \\
\hline $\mathrm{NH}_{4} \mathrm{Cl}+\mathrm{CaCO}_{3}\left(5 \mathrm{~g} \mathrm{l}^{-1}\right)$ & $3.7 \pm 0.4$ & $6.2 \pm 0.1$ & 0 & $48 \pm 3$ & 0 & $48 \pm 3$ \\
\hline$\left(\mathrm{NH}_{4}\right)_{2} \mathrm{SO}_{4}+\mathrm{CaCO}_{3}\left(5 \mathrm{~g} \mathrm{l}^{-1}\right)$ & $3.9 \pm 0.4$ & $6 \cdot 2 \pm 0 \cdot 1$ & 0 & $55 \pm 4$ & 0 & $55 \pm 4$ \\
\hline $\mathrm{NH}_{4} \mathrm{NO}_{3}+\mathrm{CaCO}_{3}\left(5 \mathrm{~g} \mathrm{l}^{-1}\right)$ & $5 \cdot 5 \pm 0.2$ & $6 \cdot 1 \pm 0 \cdot 1$ & 0 & $42 \pm 2$ & 0 & $42 \pm 2$ \\
\hline L-Glutamic acid $+\mathrm{CaCl}_{2}\left(5 \mathrm{~g} \mathrm{l}^{-1}\right)$ & $4 \cdot 8 \pm 0 \cdot 1$ & $7 \cdot 0 \pm 0 \cdot 1$ & 0 & $50 \pm 3$ & 0 & $50 \pm 3$ \\
\hline $\mathrm{NH}_{4} \mathrm{Cl}+$ phosphate $(100 \mathrm{mM})$ & $2.5 \pm 0.3$ & $6.7 \pm 0.1$ & $45 \pm 3$ & $\overline{0}$ & 0 & 0 \\
\hline
\end{tabular}

* The values, expressed as $\mu \mathrm{mol}$ per litre of culture, are the mean of at least two assays, \pm the range of results.

$\dagger$ This medium is the basal medium.

present as traces, and DL-alanine gave good growth and moderate antibiotic production (Table 3).

Effect of ammonium ions on iturin production. When glutamic acid of the basal medium was replaced by ammonium ions at the same molarity, no iturin $\mathrm{A}$ was detected in the culture medium (Table 4). As the $\mathrm{pH}$ was very low, $\mathrm{CaCO}_{3}\left(5 \mathrm{~g} \mathrm{l}^{-1}\right)$ was added; in these conditions, the $\mathrm{pH}$ was kept at 6.2 but no antibiotic was detected in the culture medium.

Ammonium chloride could inhibit the production of antibiotic in several ways: e.g. inhibition of the synthesis of $\beta$-amino acids, inhibition of the formation of cyclic lipopeptide or prevention of the excretion of the antibiotic from the cells into the culture medium. This last possibility was tested on cells grown on media containing ammonium chloride and neutralized or not with $\mathrm{CaCO}_{3}$. Bacteria were extracted with chloroform/methanol $(2: 1, \mathrm{v} / \mathrm{v})$ and the extracts were tested for the presence of iturin A in comparison with the extract obtained from cells grown in the basal medium. After thin-layer chromatography on silica gel 60 in the solvent chloroform/methanol/water ( $65: 25: 4$, by vol.) and bioautography, iturin A was detected only in 
the cells grown in the medium containing ammonium chloride neutralized with $\mathrm{CaCO}_{3}$. Iturin $\mathrm{A}$ was absent in the cells grown in the medium containing ammonium chloride without $\mathrm{CaCO}_{3}$ and in the cells grown in the basal medium (Table 4). Thus, at acidic pH (4.2), there was no synthesis of iturin $\mathrm{A}$; at higher $\mathrm{pH}(6 \cdot 2)$, synthesis occurred in the presence of ammonium chloride but the addition of $\mathrm{CaCO}_{3}$ prevented the excretion of antibiotic into the medium.

The inhibition of iturin A synthesis by ammonium chloride at low $\mathrm{pH}$ could occur before or beyond $\beta$-amino acid synthesis. If the latter is true, $\beta$-amino acids might be found in the cells either in the free state or as derivatives. The cell extracts obtained with chloroform/methanol $(2: 1, \mathrm{v} / \mathrm{v})$ were tested for the presence of $\beta$-amino acids (Table 4$). \beta$-Amino acids were not detected in the cells grown in medium containing ammonium chloride, either in the free form, or after hydrolysis of the extract with $6 \mathrm{M}-\mathrm{HCl}$ for $8 \mathrm{~h}$ at $150{ }^{\circ} \mathrm{C}$. Thus, when the $\mathrm{pH}$ decreased to $4 \cdot 2, \beta$-amino acid synthesis was inhibited, while at higher $\mathrm{pH}(6 \cdot 2) \beta$-amino acids were synthesized and incorporated into iturin molecules.

The influence of the nature of the anion of various ammonium salts was studied by replacing ammonium chloride by the same molarities of ammonium sulphate or ammonium nitrate in the culture medium. In all cases, when the $\mathrm{pH}$ was maintained at 6.2 by $\mathrm{CaCO}_{3}$, iturin $\mathrm{A}$ was not excreted into the medium but did accumulate in the cells (Table 4).

Effect of calcium ions on iturin production. The influence of calcium ions was tested more precisely. In the basal medium (final pH 6.9), the solubility of $\mathrm{CaCO}_{3}$ was very low and it was replaced by calcium chloride $\left(5 \mathrm{~g} \mathrm{l}^{-1}\right)$. In these conditions, iturin A was not found in the culture medium but it accumulated in the cells (Table 4). Moreover, in the medium containing ammonium chloride, when the $\mathrm{pH}$ was brought to 6.7 by phosphate $(100 \mathrm{~mm})$ instead of $\mathrm{CaCO}_{3}$ addition, iturin $A$ was found in the culture medium and not in the cells (Table 4). Thus, these results show that calcium ions prevent excretion of iturin $A$.

\section{DISCUSSION}

Iturin A production was studied in a synthetic medium containing phosphate, glucose and glutamic acid as the main components. Mannitol, fructose and sucrose were better carbon sources than glucose for iturin A production. Limitation of growth by phosphate led to a decrease in growth and in iturin A production but did not modify the relative cell yield of antibiotic. The increased production observed at higher concentrations of phosphate is not in agreement with previous results on synthesis of other antibiotics (Martin \& Demain, 1980).

The effect of amino acids that are structural components or possible precursors of iturin $\mathrm{A}$, used as sole nitrogen source in the basal medium, was studied. Based on specific yield ( $\mu \mathrm{mol}$ iturin per litre of culture and per unit of growth measured as $\mathrm{OD}_{600}$ ), L-glutamic acid, D- or Laspartic acid and L-asparagine produced equivalent yields of antibiotic. The yields obtained with L-serine, L-glutamine and D-asparagine were about threefold lower. A similar decrease in antibiotic synthesis has been reported with the D-phenylalanine and D-ornithine constituents of bacitracin (Haavik, 1979), D-valine, D-isoleucine and allo-D-isoleucine of actinomycin D (Katz, 1960), and D-phenylalanine of polymyxin B (Srinivasa \& Ramachandran, 1979). This inhibitory effect was explained if the L-amino acid, instead of the D-isomer, is the substrate of the multienzyme system responsible for the antibiotic synthesis (Katz \& Weissbach, 1963; Leung \& Baxter, 1972).

The addition of ammonium chloride to the culture medium lowered the $\mathrm{pH}$ to $4 \cdot 2$ and thus inhibited the synthesis of iturin $\mathrm{A}$. When the $\mathrm{pH}$ was maintained at $6 \cdot 2$ by phosphate buffer, the antibiotic was synthesized normally and excreted into the culture medium. However, when the $\mathrm{pH}$ was brought to $6 \cdot 2$ with $\mathrm{CaCO}_{3}$, iturin $\mathrm{A}$ synthesis was normal but excretion into the medium was totally inhibited. A similar result was observed when calcium ions were added to the basal medium. Thus, it seems that calcium ions modify the permeability of the cell envelope to iturin A. Although no explanation can be proposed at the present time, this observation provides an interesting model to explore the mechanism of excretion of antibiotics into the culture medium. Further work is currently in progress. 
This work was supported by the Centre National de la Recherche Scientifique (UA no. 1176 and PIRMED AIP-ASP 'Antibiotiques'). We are grateful to Y. Serrari for her assistance.

\section{REFERENCES}

Besson, F., Peypoux, F., Michel, G. \& Delcambe, L. (1976). Characterization of iturin $A$ in antibiotics from various strains of Bacillus subtilis. Journal of Antibiotics 29, 1043-1049.

Besson, F., Peypoux, F., Michel, G. \& Delcambe, L. (1978). Identification of antibiotics of iturin group in various strains of Bacillus subtilis. Journal of Antibiotics 31, 284-288.

Chevanet, C., Besson, F. \& Michel, G. (1986). Effect of various growth conditions on spore formation and bacillomycin L production in Bacillus subtilis. Canadian Journal of Microbiology 32, 254-258.

Formica, J. V. \& Waring, M. J. (1983). Effect of phosphate and amino acids on echinomycin biosynthesis by Streptomyces echinatus. Antimicrobial Agents and Chemotherapy 24, 735-741.

HaAVIK, H. I. (1979). Amino acid control mechanism for bacitracin formation by Bacillus licheniformis. Folia microbiologica 24, 234-239.

HAAVIK, H. I. (1981). Effect of amino acids upon bacitracin production by Bacillus licheniformis. FEMS Microbiology Letters 10, 111-114.

Isogai, I., Takayama, S., Murakoshi, S. \& Suzuki, A. (1982). Structures of $\beta$-amino acids in antibiotics iturin A. Tetrahedron Letters 23, 3065-3068.

Ito, M., AIDA, K.\& UemurA, T. (1969). Studies on the bacterial formation of a peptide antibiotic, colistin. III. On the biosynthetic pathway of $\alpha, \gamma$-diaminobutyric acid and the relationship between colistin formation and the amino acid metabolism in Bacillus colistinus Koyama. Agricultural and Biological Chemistry 33, 949-958.

Ito-Kawaga, M., Koyama, M. \& Kondo, S. (1983). Peptide antibiotic K-582 production in relation to amino acid metabolism in Metarrhizium anisopliae. Journal of Antibiotics 37, 487-493.

Jutisz, M. (1960). Acides aminés et peptides. In Chromatographie en chimie organique et biologique, vol. 2, p. 373. Edited by E. Lederer. Paris: Masson.

KATZ, E. (1960). Influence of valine, isoleucine and related compounds on actinomycin synthesis. Journal of Biological Chemistry 235, 1090-1094.

KATZ, E. \& WeIsSBaCH, H. (1963). Incorporation of ${ }^{14} \mathrm{C}$-labelled amino acids into actinomycin and protein by Streptomyces antibioticus. Journal of Biological Chemistry 238, 666-675.
Katz, E., Waldron, C. R. \& Melon, P. (1961). Role of valine and isoleucine as regulators of actinomycin peptide formation by Streptomyces chrysomallus. Journal of Bacteriology 82, 600-608.

LEUNG, D. C. \& BAXTER, R. M. (1972). Substrate derived reversible and irreversible inhibitors of the multienzyme I of gramicidine $\mathrm{S}$ biosynthesis. Biochimica et biophysica acta 279, 34-37.

MACH, B. \& TATUM, E. L. (1964). Environmental control of amino acid substitutions in the biosynthesis of the antibiotic polypeptide tyrocidine. Proceedings of the National Academy of Sciences of the United States of America 52, 876-883.

Martin, J. F. \& Demain, A. L. (1980). Control of antibiotic synthesis. Microbiological Reviews 44, 230 251.

Matteo, C. C., Glade, M., Tanaka, A., Piret, J. \& Demain, A. L. (1975). Microbiological studies on the formation of gramicidin S synthetases. Biotechnology and Bioengineering 17, 129-142.

Mhammedi, A., Peypoux, F., Besson, F. \& Michel, G. (1982). Bacillomycin F, a new antibiotic of iturin group: isolation and characterization. Journal of Antibiotics 35, 306-311.

Peypoux, F., Guinand, M., Michel, G., Delcambe, L., DAS, B. C., VARENNE, P. \& Lederer, E. (1973). Isolement de l'acide 3-amino-12-méthyl tétradécanoïque et de l'acide 3-amino-12-méthyl tridécanoïque à partir de l'iturine, antibiotique de Bacillus subtilis. Tetrahedron 29, 3455-3459

Peypoux, F., Guinand, M., Michel, G., Delcambe, L., DAS, B. C. \& LeDERER, E. (1978). Structure of iturin A, a peptidolipid antibiotic from Bacillus subtilis. Biochemistry 17, 3992-3996.

Peypoux, F., Marion, D., Maget-Dana, R., Ptak, M., DAS, B. C. \& MiChEL, G. (1985). Structure of bacillomycin F, a new peptidic antibiotic of the iturin group. European Journal of Biochemistry 153, 335-340.

SRinivasa, B. R. \& Ramachandran, L. K. (1979). The polymyxins. Journal of Scientific and Industrial Research 38, 695-709.

VANDAMme, E. J. \& Demain, A. L. (1976). Nutrition of Bacillus brevis ATCC 9999, the producer of gramicidin S. Antimicrobial Agents and Chemotherapy 10, 265-273. 